\title{
Digitalizing 1947: A Postmodernist Analysis of the Shifting Faces of Communitarian
}

\author{
Identity \\ * Dr. Asma Aftab, Assistant Professor (Corresponding Author) \\ ** Sadia Akram, PhD Scholar \& Lecturer \\ *** Dr. Muhammad Asif, Assistant Professor
}

\begin{abstract}
This paper deals with the problem of identity during and after the Partition of the Indian Subcontinent in 1947. It focuses on the portrayal of the shifting faces of communitarian identity/politics by analyzing two digital versions of this historical event - one is Mehreen Jabbar's drama-film Ramchand Pakistani and the other is the adapted version of Razia Butt's novel Bano, broadcast by a private T.V Channel with the title of Dastaan. Based on the postmodernist shift from performance to performance, our argument foregrounds the digital representation of 1947 which offers new angles to view the subaltern story(ies) vis-à-vis the official history of nationalism by showing different characters who experience a fleeing sense of identity in their attempt to cope with the trauma of displacement and violence during 1947. In this article, the textual and digital versions of 1947 are read as cultural texts which embody the human and subjective experience and perceptions of ordinary human subjects from both sides of the divide, either during the historical event of Partition as sufferers or survivors or in current scenario in the wake of the politics of mistrust between Pakistan and India. The study concludes that digitalizing the history of 1947 offers an introspective representation of myriad experiences of people and their past which is different from a retrospective illustration of official history with its nationalist certitude and xenophobia.
\end{abstract}

Keywords: Digitalizing Past, Subaltern History, Communitarian Identity, Performance, Paratextuality, Nationalist Xenophobia.

\section{Introduction}

As one significant theme of South Asian literature, different narratives on the Partition of United India in 1947 represent myriad ideological and political orientations of different authors writing on the subject. The subject has become more complicated when it gets engaged with the complex themes of migration, nationalism, communal politic, and fleeting sense of identity experienced by the colonized subjects. This theoretical complexity offers new ways and angles to look at different imaginative narratives with their myriad ways of telling the subaltern stories, showcasing what the postmodernist thinker Lyotard has called the "incredulity towards all meta-narratives" (as cited in Bertens, 2003, p.65).

In challenging and questioning the grand narratives, these Partition narratives seem to simultaneously foreground the anxieties, struggles, and sufferings of ordinary humans who are, simultaneously, the subject and object of such grand nationalist ideologies and their justifying rhetoric.

\section{Selection of Visual and Fictional Narratives}

In recent times, many works on the subject of 1947 have been adapted into digital/visual versions and during this process, have sometimes transcended their textuality, both in terms of their affective and cognitive impact as well as their representation of a complex and multilayered historical reality. The two visual narratives that we have selected in this article on the subject of 1947 include a TV serial named as Dastaan on Hum TV in 2010 which is an adapted version of the novel Bano by the renowned woman novelist Razia Butt (1971) and the drama film Ramchand Pakistani penned by Javed Jabbar and directed by Mehreen Jabbar (2008). Both works represent the predicament of ordinary men and women in the historical moments of crisis and cataclysm - Dastaan represents it in

* Department of English, Government College University, Faisalabad Email: asmaaftabkhan@gmail.com

** Department of English, Government College University, Faisalabad Email: sadia_akram1 @ hotmail.com

*** Department of English, Government College University, Faisalabad Email: masifshafee@ yahoo.com 
and around 1947 Partitioning of India, whereas Ramchand Pakistani fictionalizes this conflict in the Post-Kargil times with a serious and escalating tension between India and Pakistan on the border at Tharparkar in Sindh. Situated in two different Spatio-temporal domains with divergent political standpoints, the first visual narrative Dastaan portrays the struggle of a Muslim woman with an increasing political consciousness suffering a chain of hardships including the massacre of her whole family after which she is forced into wedlock with a Sikh and eventually becomes the mother of his child. As against it, Ramchand Pakistani visualizes the predicament of a low-caste Hindu family in the wake of a war-like situation between India and Pakistan. The story begins when the minor boy Ramchand mistakenly crosses the border near Tharparkar, in the Pakistani Province Sindh, and is captured along with his father under the suspicion of being Pakistani spies by the Indian Border Security Forces.

\section{Theoretical Framework}

By using myriad theoretical debates from Postmodernism, the present analysis argues that the digital representation of 1947 Partition in the selected works attempts to challenge the mainstream historiography employing retrieving the perspectives and voices from subaltern history. That these voices are lost and forgotten in the so-called meta-narratives of nationalist history is a case in point as these texts seek to locate the complex and even mutually contradictory accounts of subaltern history with their angst and agency running parallel, sometimes counter to the official history of men in power. Using a similar lens that the subaltern historians like Amin (1995) and Guha (1997) employed in their project of retrieving Indian history from the perspective of the subaltern, our analysis locates the presence of such voices in the digital version of these visual narratives. However, parallel to these narratives, we have also discussed some YouTube videos on the subject of 1947 as paratexts by emphasizing how this inclusion has further problematized the subject of communitarian politics/identity in contrast to their representation in the textual version.

It is very pertinent to mention here that the rise of digital humanities has brought about considerable change in the ontological outlook of contemporary culture, underscoring the perennial postmodernist anxiety about how our perception of reality is always shaped and influenced in the backdrop of the medium of representation that we choose or that chooses us. Felluga (2015) argues that the transition from a spoken word to a written word and then from a printed word to a visual image has brought about an unimaginable transformation in our perception of a social reality vis-à-vis technology and our sense of subjectivity. This digital version of history in the case of 1947 Partition has become a unique project when it transcends its textuality and impacts our perception by replacing the former practice of close reading of a main story with many mini-stories which in the words of Hutcheon (2002) are a mixture of fact and fiction. In this way, according to Mcgann (2001), reading becomes performative, not merely challenging the grand narratives "from above", but is potentially what contemporary postmodernism terms as "deformance" with its ongoing dialogue between the screen and the humans (p.207). In other words, by taking a step further than what Baudrillard (1981/1994) calls a hyperreal with its "precession of simulacra" ( p.1), these digital versions, albeit their discursivity, produce radically different effects on the onto-existentialist outlook of their readers or spectators.

It is also pertinent to mention here the postmodernist notion of paratextuality which in view of Hutcheon and Valdés (2002) is meant to "make space for the intertexts of history within the text of fiction" (p.83). That this transition from a poststructuralist pantextualism into a postmodernist paratextuality allows readers to locate historical and cultural retrieval in divergent texts, leaving many gaps and paradoxes which can only be filled/reconciled when these narratives are read as paratexts to each other. Hence, this postmodernist oscillation from performance to deformance in the act of reading offer more diverse angles to the same texts in their digital as well as textual forms embodying many tensions regarding this important event in South Asian history.

\section{Methodological Implications}

Having discussed the theoretical debates which inform our analysis in the following lines, we will now move to a brief discussion of some methodological implications which are born out of our theorization on the subject of 1947 Partition and its digitalized representation. For to locate the marginalized voices and peripheral stories of these subalterns who have been treated as mere objects in mainstream nationalist history, one needs to contrive more wavering and wide-ranging paratextual 
trajectories that suspect more than they subscribe to the monolithic and unitary consciousness of a historical text in the nationalist archive.

Another important angle in this postmodernist analysis is to see the highly contested terrain of nationalist politics and their impact on the micropolitics of a community by questioning the historical and political logic of two-nation ideology and the subsequent making of two separate states? How does the communal identity of people shape their political and personal outlook vis-à-vis their nationalist and humanist values? Given the complexity and multivocality of these questions, they involve what Roy has called "an engagement with the implications of dividing a country based on religion" (2010, p.135). By presenting the mutually contradicting religious or secular identities of human subjects among Hindus and Muslims, these visual narratives have deflated the nationalist ideologies with their grand utopias of freedom for ordinary people. They have also engaged and offered some important lessons that both India and Pakistan could or should learn from their past and present.

In so doing, these visual narratives, unearth the story of ordinary men and women by making them simultaneously the insiders and the outsiders of a conflict. They are included in it because they are often, though mistakenly, recognized based on their communal or national identity and excluded from it. After all, as ordinary citizens, they are largely ignorant of the mega political or strategic relations between two geographically close yet inimical neighbors. In this way, this digital representation tends to interrogate more than it integrates the official version of nationalist history with its smooth and seamless categorization of people based on their communal identities. In other words, these works simultaneously represent and problematize the justifying claims for or against the concomitant political ideologies which informed the division of India in 1947 by laying bare the contestatory nationalist politics. For example, if nationalism has been a cementing force uniting people of the Subcontinent against the empire as their shared enemy, the same notion of nationalism, when shaped on communal bases, becomes a divisive connotation with a host of different, even warring ideological and political choices made by both Muslims and Hindus.

On the other hand, parallel to problematizing the nationalist dimension, the visual representation of 1947 also presents the human/ist side of this historical event by showcasing certain limitations in nationalist ideology with its communalist rhetoric. Hence, every time it is not the communal or nationalist politics that shape the individual agency and subjectivity as there are individuals, from both sides of the divide, who act according to their subjective outlook with their denial to comply with the rigid standards of nationalist politics with their xenophobia. In Dastaan, this is manifest in Bano's elder brother Saleem who remains convinced of a Hindu-Muslim fraternity for a long time and hates the League's claims of a separate state for Muslims. Likewise, one Hindu neighbor in the drama, during the violence and lynching of the Hindu/Sikh mob saves Bano and her mother by killing his Sikh friend and by staying true to his bond with Bano's family.

In the same way, Ramchand and his father despite being mistreated by Indian police as Pakistani spies, find some individuals in and around the Indian jail who view them with empathy and compassion and consider them as human beings rather than antagonistic fellows. Thus Ramchand's bond with the woman officer working in the prison and her treatment with this 'so-called Pakistani spy' transcends the jealous and intolerant xenophobia of nationalist politics. In this way, these works have represented the ebb and flow in nationalist politics by highlighting the shifting face of communitarian identity and suggest that every time this communication does not shape the subjective human agency and choice made by people from both sides of the communal/nationalist divide. In this way, these visual narratives engage with the thorny and controversial nature of the 1947 Partition by underscoring the arbitrary nature of communal politics with their denial to accept the neat binaries between Hindus and Muslims on clear-cut ideological grounds.

However, parallel to a succinct critique of nationalist and communitarian politics by underscoring their insufficiency, these two versions also problematize and challenge the simplistic claims of a secular-humanist angle by showing the loss of humanist values of coexistence, love, and tolerance during the 1947 mayhem. In this way, these visual narratives highlight the inadequacy of both communal and secular angles as, they, alone fall short of explaining the lived experiences of ordinary people like Bano or Ramchand, who either become subject to blind nationalist zeal or the obdurate and rigid politics of the two competing rivals. 


\section{Digitalizing 1947 Narratives: Points of Analysis \\ Dastaan}

The main focus of Dastaan as a televised version of the novel is on the shifting and fleeting layers of identity concerning the communitarian politics making a heady appearance in the political landscape after 1930. The story is set in the backdrop of the emerging idea of Muslim exceptionalism that in view of Raja (2010) has a unique historical genealogy in South Asian discursive accounts. The story unfolds itself in the background of this distinct sense of communal nationalism in Indian politics as the narrative offers a gradual yet inevitable evolution of this politics of difference and identity, especially in the case of Muslims with their struggle for survival against a Hindu majority.

With its highly emotive and somewhat inflated representation of communal identity, the narrative presents a vivid picture of how love morphs into hate and erstwhile neighbors and friends become thirsty for each other's blood. This nationalist euphoria is very much evident in a traditional family of Ludhiana, whose younger son Hasan is an enthusiastic worker of League. However, his political convictions bring about serious cracks in the otherwise close kinship of Hasan's family with that of Saleem with whom Hasan's aunt Surrya is wedded quite recently. This irony is further heightened when Hasan falls in love with Saleem's sister Bano who is shown to be divided between her sisterly obligation towards her brother - an arch-enemy of League and her growing affection for Hasan. As the story unfolds, the tension between Hasan and Saleem grows more intense, dividing the family, especially the women as the hapless victim of nationalist politics since they are expected to decide their loyalty to either of the poles they have close emotional bonds with. Two most important illustrations of this can be seen in the case of Surrya who is coerced not to see her nephew Hasan on account of his political beliefs. Like her, Bano becomes subject to her brother's chagrin who, based on his more liberal communal outlook, does not want to wed her to Hasan and even prefers his Hindu friend as his sister's future husband.

The story portrays this conflict more vividly after the 1945-46 Election, when after the clear victory of the Muslim League, the dream of a separate homeland for Muslims became visibly clear. Saleem, in this situation, remains convinced with his vision of a United India and like any proCongress man has faith in the philosophy of communal harmony and coexistence. However, the first rude shock to his political certitude comes in the form of communal riots which break out in the nearby village where some of his close family friends are looted with their daughters raped and killed by the Hindu and Sikh hooligans. The story takes a dramatic shift when Saleem feels insecure about his own family, especially his sister Bano and his wife Surrya - pregnant with his first child. The events, afterward, demonstrate an intolerant nationalist-communal politics, turning friends into violent foes and trusted allies into indifferent or unkind aliens. The drama, in this way, offers an implicit critique to the politics of communalization with their total reversal of the otherwise secular ideals by Nehru and other Congressmen. The entire family, including Saleem, his brother, father, and wife die while protecting each other and the story offers an extremely emotional portrayal of Saleem's sense of guilt on having trusted Hindus and Sikhs as his brethren.

From this point onwards, Dastaan gives us a gory picture of communal riots, rapes, and forced migration that millions of people suffered at the time of Partition. This is presented most forcefully in the case of Bano who along with her mother survives to see and suffer this bloodbath. Twice her caravan is ambushed by Hindu and Sikh mob, after which her poor mother dies, leaving her alone and forsaken, to be forcibly married to a Sikh and eventually giving birth to a boy that she detests as a living symbol of shame and humiliation inflicted on her by the Sikh community. In one of the touchiest scenes in the play, when she reaches Pakistan after the accidental death of her husband, she tells Hasan that 'her son is, in fact, the abuse that her husband has given to the whole nation'. In so doing, she idealizes her brothers in Pakistan who she thinks will take revenge from the Sikhs for all the misery and shame she has suffered.

However, the utopian fancy with which Bano comes to the Land of Pure turns into a grim reality when she realizes that her brethren in faith living in Pakistan are not what she thought them to be. Unlike the mythical Bin Qasim in the history of Islam that Bano aspires as the ultimate savior of her honor, her brothers in Pakistan are not burning with any sense of inflated honor and vengeance. Instead, many of them are shown to be having a bad eye on Bano on account of her innocent beauty. Echoing a rather bitter similarity with Manto's (2011) rather provocative portrayal of Razakars in his short story Sakina, Bano, becomes subject to the lust and licentiousness of a man that she trusts as a 
genuine person. The drama, in this way, offers an acutely emotive and profound description of a nottoo-rosy picture of reality in the promised land of Pakistan causing disenchantment in many immigrants, including Bano, who saw the dawn of freedom turning into what Faiz has termed something "stain-covered, night-bitten"

Besides the tragic fate of a multitude of women suffering rape, abduction, and forced marriages during 1947, the fiction on the subject of 1947 is not less distressing a representation of children and their vulnerability - from a neonate or unborn child clubbed or stabbed to death in the womb of (her) mother to a lactating infant dying of hunger as her mother is either dead or lost, to the traumatic existence of many teens suffering death, disease or displacement during this exodus. Dastaan is no less tragic in presenting the predicament of Bano's child who is sinned more against than sinning. If, on one hand, he faces the spiteful remarks of his mother who considers him a sorry reminder of her past, on the other hand, he is ostracized in the nascent Muslim community that suspects him based on his Sikh paternity. It is ironic to see that the fate of such children and women does not get any better after the making of two independent states as they were destined to suffer if they fit and suffer if they don't fit into these divisive communal categories of Muslim/Hindu woman or child.

This once again demonstrates our argument in the previous lines that in highlighting the crime against women and children, the 1947 Partition fiction represents the essential paradox of communal identities and politics. Moreover, in its denial to accept the fixed and seamless categories of the socalled victim or culprit, the fiction shows that the culprit at one side is often deemed as a victim on the other and the simple question of who initiated violence and abuse and who resorted to it as retaliation becomes all too puzzling and clouded in the massive body of writings on the subject of 1947 Partition.

Though a series of imaginative texts have acknowledged that in the violence of 1947 "both sides killed... and stabbed...speared and clubbed...tortured [and] raped" (2006, p.1), however, every version has its way of locating the responsibility on either of the people based on the subjective perception of the authors. For instance, Singh's (2006) Train to Pakistan represents the imaginative town of Mano Majra as an ideal abode of communal harmony and tolerance until a train loaded with the dead bodies of Sikhs arrives at the place. This instigates the Sikhs living there who are resolute to send a train full of the dead Muslims to Lahore as part of their revenge. However, the story takes a rather suggestive turn when one Sikh is shown to be saving the whole train of Muslim refugees by sacrificing his life, hence problematizing the obdurate nationalist politics with their increasing communalization in shaping the choices and actions of people. Contrary to this, Sidhwa (2010) in Cracking India takes a reverse position when she represents the outburst of communal violence in Lahore as a reaction to a train from Gurdaspur where everyone was "dead...butchered...all Muslim (p.70). Seeing this, the otherwise sweet and loving Ice Candy Man morphs into a communal fanatic who is determined to take revenge for this murder and abuse from Sikhs and Hindus, hence violence from one side is responded with more brutal and inhuman acts of violence from the other side. Nonetheless, parallel to Sidhwa's critique of the "non-violence credos" of Gandhi and Nehru (Roy, p.53), the fictional representation of 1947 also questions the departing Raj for their blatantly criminal negligence in foreseeing, let alone stopping, such human catastrophe as its foremost administrative obligation.

However, the visual narrative of Dastaan takes a suggestive turn in the end when, unlike Manto and Rushdie's pessimistic aesthetics with its singular focus on abuse and betrayal, it seeks to search nationalist ideal while 'wavering somewhere between promise and reality' (Anwar, 2012). The last episode of Dastaan vividly describes it when Bano kills her Pakistani tormentor in a state of make-believe as if she has killed her Sikh husband. The last scene depicts her in a dream-like situation when she utters the word Pakistan Zindabaad by imagining Pakistan to be free from all impurities and offers a dim hope silhouetting out of the grim present. In this way, the digital version of Dastaan seems to produce an effective response that is visibly different from its textual form, reinforcing our principal argument about the subtle onto-aesthetic effects of a postmodernist transition from performance to deformance.

\section{Ramchand Pakistani}

As stated before, Jabbar's Ramchand Pakistani (2008) seems to grapple with the same theme of children's sufferings and struggle against the odds and ills of nationalist euphoria even years after the division of the Subcontinent. The film presents the agony of parting in the case of a Pakistani Dalit 
family when a less than ten years old child "crossed one line and three lives changed forever". Hence Ramchand, the innocent Hindu boy who is ignorant of the strained relations of India and Pakistan and the ensuing strategic tension between them, mistakenly crosses the border and is caught by Indian forces who ironically suspects him to be 'spying' for Pakistan. His tragedy becomes more intense in the wake of rising mistrust between India and Pakistan as Ramchand and his father continue to be treated as suspects in an Indian jail for five years. The movie further unmasks the discriminatory and unjust prejudice of high-caste when Ramchand, on account of his Dalit identity, is forbidden to touch the dishes of the female police officer, on which she is told by a constable rather ironically "Madam, in jail there is no one Dalit or Brahman, here all are the same". However, as the film progresses, the same police officer develops a human bond with Ramchand by acknowledging that human emotions and bonds are beyond any low and high caste.

On the other side, the film presents the turbulent life of Ramchand's mother who does not know how to come out of this quagmire which has 'torn apart her once united family and happier living' in just one moment. At one time, when she is almost disappointed by the possible return of her husband and son, she feels a little inclined towards a Muslim vendor who is also attracted towards her. Nonetheless, the film portrays the fixed communal identity of both Ramchand's mother and her expected lover who is rebuked by his friend not to be carried away with such a shameful act of loving an "Achoot" (Untouchable). At the end of the film, though Ramchand and his father are released from the prison one by one, however, before this happens, both are bound to accept the overarching communal or nationalist categories which continue to determine, even dominate their subjectivity and destiny in the twin settings they belong to. In Indian prison, they are treated as Pakistani spies and when viewed with the narrow lens of Hindu nationalist politics, are doubly suspected on account of their Dalit identity and poor class. In this way, the film vividly portrays the complex human and nationalist dimensions of the 1947 Partition.

One important question that the film raises is that can India and Pakistan ever live with each other like tolerant democratic neighbors? This is evident in the film where during his imprisonment in India, Ramchand learns to see these borders as objective political reality which shapes their distinct identity as the citizens of India or Pakistan. Unlike Bishan Singh in Manto's (1998) Toba Tek Singh who remains irreconciled with the logic of Partition by insisting on the arbitrary configuration of borders, Raamchand and his father are made to acknowledge how crucial the borders have become in the newly-emerging political realities when a fellow prisoner says: "Border ko gaali na do, agar yeh border na hota to tum Bengali na hotay, itni buri cheez nahi hay ya border"[Don't abuse the border, had there been no borders, none of us would have been Bengali, or Pakistani or Indian. the borders are not that bad] (Jabbar, 2008).

On a comparative note, this dialogue offers a stark reversal to Manto's dubiety and disdain for the spatial configuration of borders and their logic of partitioning the land into insubstantial and shadowy division. Unlike it, Ramchand's outlook is cognizant of the historical and material validity of these borders for both India and Pakistan as two sovereign states. Not only this, the film tends to highlight the need to follow the policy of live and let live by accepting and respecting the sovereignty of each other without further fueling the xenophobic and expansionist agenda of the militant fractions from either side.

The film in this way offers a succinct critique of the intolerant politics of Hindutva in presentday India with its blatant denial to respect the territorial sovereignty of Pakistan by clinging to their myth of Mahabharta. It is very pertinent to mention another paratextual site of Javed Jabbar's conversation (2011) where he gives a square rebuttal to Indian intellectuals' denigration of Pakistani nationalism as if Pakistan has no historical basis, whatsoever, for its independent existence. He highlights the irony that while Indian intellectuals and diplomats dare to question the rationale of Pakistan, none of the Pakistani Intellectuals including him are inclined to do it by doubting the logic of India. Jabbar also argues against the myth of Mahabharta that implies that Pakistan is carved out of India as historically speaking this whole region which currently constitutes India and Pakistan, despite a long and shared Indo-Persian past, has never been united under any Muslim or Hindu dynasty including the Mughals. In this way, Jabbar has distanced himself from the dominant proclivity of many Indo-Pak intellectuals and writers who view the making of Pakistan as tantamount to the partitioning of India, as if an erstwhile unity has been ripped apart. On the other hand, he seems to offer a more grounded explanation by calling it what Leila Gandhi has termed as the theme of 
Independence which runs parallel to this theme of Partition in the discursive account on 1947 from both India and Pakistan (Mehrotra, p.195). On a related note, Jabbar acknowledges the historical and political situatedness of Muslim or Hindu nationalism by viewing it as an enabling category that should not become the self-serving ideology for the xenophobic politics in India or Pakistan. Such intellectual position views the making of two sovereign states as an objective necessity of the region by questioning at one hand, the so-called organic unity of India and by accentuating a peaceful paradigm of live and let live as the best alternative for the twin neighbors.

However, such advocacy of peace and co-existence also questions a rather singular valorization of peace based on an outright denial of ultra-orthodox Indian politics with their expansionist ambitions not merely against Pakistan but for other neighboring states too (including Bangladesh, Sri Lanka, and Nepal. In another paratextual site, Jabbar critiques this vacuous position of a so-called peace perspective which is based on a flawed notion of communal harmony and coexistence indicating that at no time in history, the pre-1947 scenario of the Subcontinent was peaceful and violence-free. Without naturalizing the devastating effect of communal abuse and violence, such historical insight is crucial for understanding the grounded political realities of the Subcontinent with their concomitantly conflicting political agendas for both Muslims and Hindus.

\section{Conclusion - Some Insights and Inferences}

Summing up the discussion, we can say that literature on 1947 is a site where history revisits itself to unmask the myriad and complex themes of nationalist history and communal politics. While all these representations have their legitimate claims and counter-claims, none of them carries an objective and total view of reality which is given by Roy (2010) demonstrates that "perhaps there is no such thing as a dispassionate, objective view when it comes to the recording of history" (p.73). Without expecting an altogether objective and dispassionate account of history, what is required is to consider and maintain what Cilano (2010) in her study of national identities has termed as a "productive critical distance" (Introduction, p.i) from a historical event like 1947. Such distance, if achieved, can offer a broader picture of the otherwise complex subject of national and communal identities by maintaining the historical specificity and situatedness of all those involved in the subject.

\section{References}

Aftab, A. (2017). The dilemma of national consciousness and the making of national culture: An analysis of the literary works by Pakistani writers (1964- 2011) [Unpublished doctoral dissertation]. National University of Modern Languages, Islamabad.

Amin, S. (1995). Event, metaphor, memory: Chauri Chaura, 1922-1992. Oakland: University of California Press.

Anwar, W. (2012, February). South Asian literature and culture. Keynote at International Conference on South Asian Literature and culture, International Islamic University, Islamabad.

Baudrillard, J. (1994). Simulacra and simulation [Simulacres et Simulation] (S. F. Glaser, Trans.). \& Ann Arbor: University of Michigan Press. (Original work published 1981).

Butt, R. (1971). Bano. Lahore: Ferozsons.

Cilano, C. Introduction. "Too Soon?: Pakistan and the 1971 War." ed. Pakistaniaat: A Journal of Pakistan Studies: Special Issue: 1971 Indo- Pakistan War 2.3 (2010): i-x. Web. 16 Apr. 2016. <http://pakistaniaat.org/index.php/pak/>.

Fazal, S. (2010, June 26). Dastaan [Video file]. Retrieved from https://www.youtube.com/watch? $\mathrm{v}=\mathrm{cVibDIqDfxU}$

Felluga, D. F. (2015). Critical theory: The key concepts. London: Routledge.

Gandhi, L. (2008). Novelists of the 1930s and 40s. In A. K. Mehrotra (Ed.), A concise history of Indian literature in English (pp. 190-218). Ranikhet: Permanent Black Publishing House, 2008.

Guha R. (Ed.). (1997). A subaltern studies reader: 1986-1995. Minnesota: University of Minnesota Press.

Hussain, H. (Producer), \& Butt, R. (Writer). (2010). Dastaan [Television series]. Lahore: Hum TV. Hutcheon, L. (2002). The politics of postmodernism. New York: Routledge.

Hutcheon, L., \& Valdés, M. J. (Eds.). (2002). Rethinking literary history: A dialogue on theory. Oxford: Oxford University Press.

Jabbar, J. "India-Pakistan: Challenges and way forward." YouTube. May 11, 2011. https://www.youtube.com/watch?v=37RzIj7BNuc 
$\overline{\text { Jabbar, M. (Director). (2008). Ramchand Pakistani [Motion picture]. Pakistan: Geo Films Museum of }}$ Modern Art.

Manto, S. H. Toba Tek Singh by Sadat Hasan Manto [Video]. (1998). South Asia Citizens Web. https://www.sacw.net/partition/tobateksingh.html

McGann, J. (2001). Radiant textuality: Literature after the world wide web. New York: Palgrave.

Mehrotra, A. (Ed.). (2009). A concise history of Indian literature in English. Palgrave Macmillan.

Qazi, A. "KLF-2019: Book Launch: Pakistaniat kya Hai? by Javed Jabbar." YouTube. Reading. March 21, 2019. https://www.youtube.com/watch?v=KmAi-FnUU5w.Karachi \& Islamabad Literature Festivals.

Raja, M. A. (2010). Constructing Pakistan: Foundational Texts and the rise of Muslim national identity, 1857-1947. Oxford University Press, USA.

Roy, R. (2010). South Asian partition fiction in English, From Khushwant Sigh to Amitav Ghosh. Amsterdam: Amsterdam University Press.

Sidhwa, B. (2010). Cracking India: A novel. Minneapolis: Milkweed Editions.

Singh, J. Jaswant Singh's exclusive talk with Dr. Pirzada, Part 1 [Video]. (2016, May 5). Moeed Pirzada | Official Website. https://moeedpirzada.pk/jaswant-singhs-exclusive-talk-with-drpirzada-part-1

Singh, K. (2006). Train to Pakistan. New Delhi: Roli Books.

Taseer, A. (2011). Manto: Selected stories. Random House India. 